- Pedro de Alcântara de

Andrade Filho

- Abrão Rapoport

- Venâncio Avancini Ferreira Alves

- 0 dilon Victor Porto Denardin

- Josias de Andrade Sobrinho

- Marcos Brasilino de C arvalho

\section{Paragangliomas of the head and neck: clinical, morphological and immunohistochemical aspects}

$\mathrm{H}$ ead and N eck Service of H eliópolis H ospital (H osphel), and Pathology Service of $\mathrm{O}$ swaldo Cruz H ospital, São Paulo, Brazil

\section{ABSTRACT}

CONTEXT: Protein marker positivity can assist in the definition of the therapeutic approach towards head and neck paragangliomas. The establishment of the therapeutic approach should incorporate the results of such an investigation.

OBJ ECTIVE: To establish criteria for benignancy and malignancy of vagal and jugular-tympanic paragangliomas, via the study of the relationships of sex, age, tumor size, duration of complaints, site, family history, presence of metastases, treatment, histological architecture and cell type with the immunohistochemical reactions to S100 protein, chromogranin and AgKi67.

DESIGN: A retrospective study of histological and clinical records.

SETIING: The Heliópolis and 0 swaldo C ruz tertiary general hospitals, São Paulo.

SAMPLE: 8 cases of head and neck paragangliomas.

MAIN MEASUREMENTS: Determination of degree of positivity to paragangliomas via immunohistochemical reactions.

RESULTS: 1). The protein markers for the principal cells (AgKi67 and chromogranin) were sensitive in $100 \%$ of the tumors when used together. 2). S100 protein was well identified in the cytoplasm and nucleus of sustentacular cells and underwent reduction in the neoplasias.

CONCLUSIONS: Chromogranin was proven to be a generic marker for neuroend ocrine tumors; $\mathrm{S} 100$ protein was positive in all 8 cases and the AgKi6 7 had low positivity in all cases.

KEY WORDS: Paragangliomas. Markers. AgKi67. Chromogranin. S100 protein.

\section{. . . . . INTRODUCTION}

$\mathrm{H}$ ead and neck paragangliomas are rare and are trueneuroendocrineneoplasias. They originate from various paraganglia, ${ }^{1}$ members of a complex and intriguing family of endocrinecellsthat present centripetal distribution with a tendency towards symmetry, extending from the middle ear and skull base region to the pelvic floor. ${ }^{2}$

All these cells are derived from the neural crest and form the diffuse dispersed neuroendocrine system. Thesekinds of cells are found in the central and peripheral nervous system and in many classic endocrine organs, for example the adrenal gland. They are distributed in the majority of body tissues, organized as isolated cells or in groups of 3 or 4 cells, exhibiting a heterogeneity of phenotypes that makes for structural diversity. There are basically two kinds of cells: the principal cells and the sustentacular cells. The former are rounded, with a dark central nucleus, eccentric, with eosinophilic granules in their cytoplasm, identified as neurosecretory granules by means of histochemical or immunohistochemical reactions, or using electron microscopy, with a halo around the membrane rim also being noted. They are grouped in nests and can be classified as light, dark and pyknocytic. The sustentacular cells, located on the periphery of these nests of principal cells (Zellballen model) are pale, with elongated nuclei and indistinct cytoplasm. $\mathrm{N}$ ear to the principal cells, axonal processes known as the mesaxonia can be observed. Endothelial and pericytic cells, and occasionally mast cells, are also found in paraganglia. ${ }^{3}$
$\mathrm{H}$ ead and neck paraganglia have an intimate relationship with vascular and neural structures. ${ }^{4,5} \mathrm{~T}$ hey have a strategic local ization that allows the development of a chemoreceptor function in response to alterations in gas concentrations in arterial blood. ${ }^{6}$ Another important aspect is the chemoreceptor-sensitive function of the carotid bodies, which are sensitive to $\mathrm{pO}_{2}, \mathrm{pH}$ and $\mathrm{pCO}$ alterations in the blood, in which the chronic hypoxemia stimulates the carotid body hyperplasia. ${ }^{7}$

These paragangliomas present approximately the samearchitecture as a normal paraganglion, with some variation in size and shape, but the main difference in this neoplasiaisthe proliferation of principal cells in nests surrounded by sustentacular cells that represent 1 to $5 \%$ of the cells of a paraganglioma and form a prominent vascular network. ${ }^{8}$ Three architectural patterns have been described: ${ }^{9} 1$ ) the normal or Zellballen model; 2) angiomatous, with largespindleor crescentshaped principal cells and the appearance of capillaries; and 3) adenomatous, with a marked similarity between the principal cells and the epithelial cells, i.e. polyhedral cells with abundant cytoplasm and columnar arrangement.

C arotid body paragangliomas are different from hyperplasia in that they present proliferation of the principal cells whereas in hyperplasia there is proliferation of the principal and sustentacular cells. ${ }^{10}$ The majority of head and neck paragangliomas contain neurosecretory granules with vasoactivesubstances like epinephrine, norepinephrine, dopamine and serotonin. ${ }^{11}$ The fact that these catecholamines are present does not signify 
that there is a biological effect. ${ }^{12} \mathrm{~N}$ evertheless, the measurement of vanil-mandelic acid is recommended as a screening method when these tumors are suspected. ${ }^{13,14}$

The clinical presentation is usually asymptomatic. Pain, hoarseness, dysphagia, H orner's syndrome, tinnitus and hearing loss may occasionally be presented. There is evidencethat these paragangliomas present as family histories, ${ }^{15,16}$ which has led to studies of oncogene identification. ${ }^{17,18}$ M ost paragangliomas are benign, but 6 to $9 \%$ of head and neck para gangliomaspresent histologically and biologically malignant behavior, ${ }^{19}$ with the appearance of mitotic cells, cell pleomorphism and central necrosis in Zellballen areas). M alignancy, widely discussed by many authors, is only fully characterized by distant metastasis, ${ }^{20}$ with there being concern regarding the lack of identified histopathological factors (i.e. the cell atypia, nuclear polymorphism and local invasion factors that are typical of malignancy). ${ }^{21} \mathrm{H}$ istological comparison between benign and malignant paragangliomas does not demonstrate any differences, ${ }^{22}$ and the most important factor among these histological factors seems to be the site of the tumor itself. Theincidence of metastasis in para-aortic paragangliomas ranges from 28 to $42 \%$. The knowledge available at present still does not allow the reasons for this difference in re lation to head and neck paragangliomas to be explained. ${ }^{21}$

Using electron microscopy, a pattern of diminution or absence of sustentacular cellswasfound in thetumor architecture of malignant paragangliomas. ${ }^{10}$ This was the first histological observation step towards predicting the clinical behavior of such tumors. It was followed by theintroduction of protein markersusing immunohistochemical methods, in order to identify prognostic factors in head and neck paragangliomas.

Various tumor markers have been tested. Some have confirmed the neuroendocrine origin of the neoplasia and others have shown up strong suspicions of malignant behavior. ${ }^{4}$ In these latter cases, even in the absence of distant metastases, there was greater tumor aggressiveness, either with the invasion of adjacent structures or with disease recurrence. In the present study, three immunohistochemical markers were used: chromogranin (Figure 1), S100 protein (Figure 2) and AgKi67 (Figure 3).

Chromogranin, the main marker for neuroendocrinecells, is a structural protein found in neurosecretory granules of principal cells. Its function is to stabilize the intra-cellular matrix of neurosecretory granules, thereby showing itself to be an excellent indicator of neuroendocrinedifferentiation. Well-differentiated tumors contain more neurosecretory granules and the undifferentiated ones have less of them. ${ }^{4}$

S100 protein, a dimeric $21-\mathrm{Kd}$ protein bonding with calcium, was isolated from the nervous system. It has been identified in sustentacular cells of autonomous ganglia, adre nal medullas and extra-adrenal paraganglia. It may also be identified in sustentacular cells of neural and neuroendocrine neoplasias. It is localized in the cytoplasm and nuclei of the sustentacular cells of extra-adrenal paraganglia. In extra-adrenal paraganglioma, it has been demonstrated that all the be nign tumors contain sustentacular cells, whereas these are seen to be absent in malignant tumors. ${ }^{4}$

The nuclear antigen AgKi67 (M iB-1) is a protein in all phases of the cell cycle except the $\mathrm{G} 0$ phase, and has a direct relationship with the growth rate of a cell population. It is an excellent marker for cell proliferation..$^{23}$

The question thus arises of whether immunohistochemistry could behelpful in the identification of benign paragangliomas and their behavior.

The objective of thiswork wastherefore, in summary, to establish clinical, histological and immunohistochemical criteria for benignancy and malignancy, by means of the retrospective analysis of 8 cases of carotid body and jugular-tympanic para gangliomas.

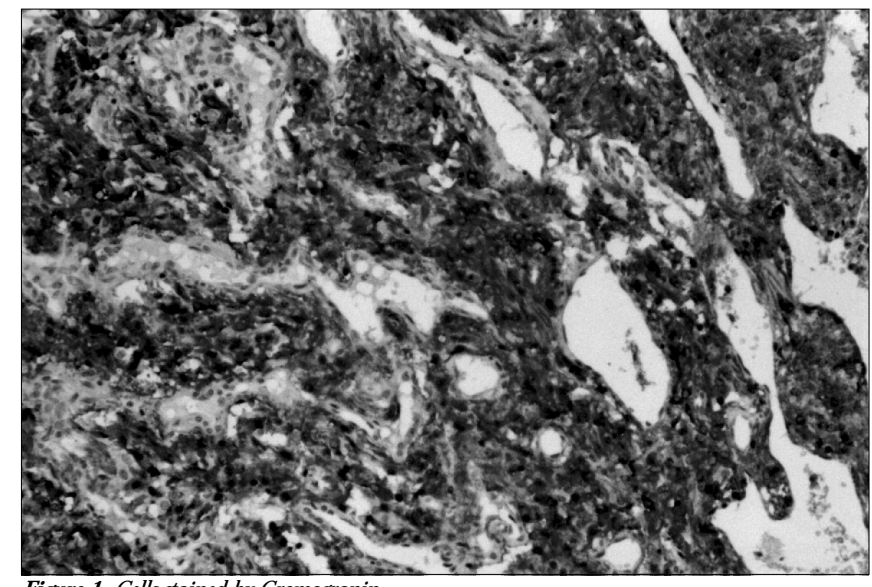

Figure 1. Cells stained by Cromogranin.

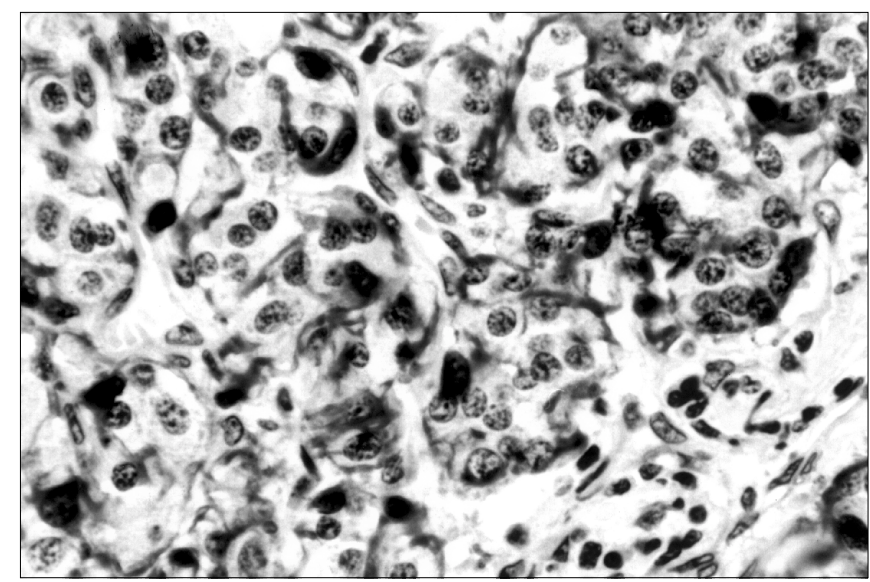

Figure 2. Sustentocullar cells stained by S100 proten.

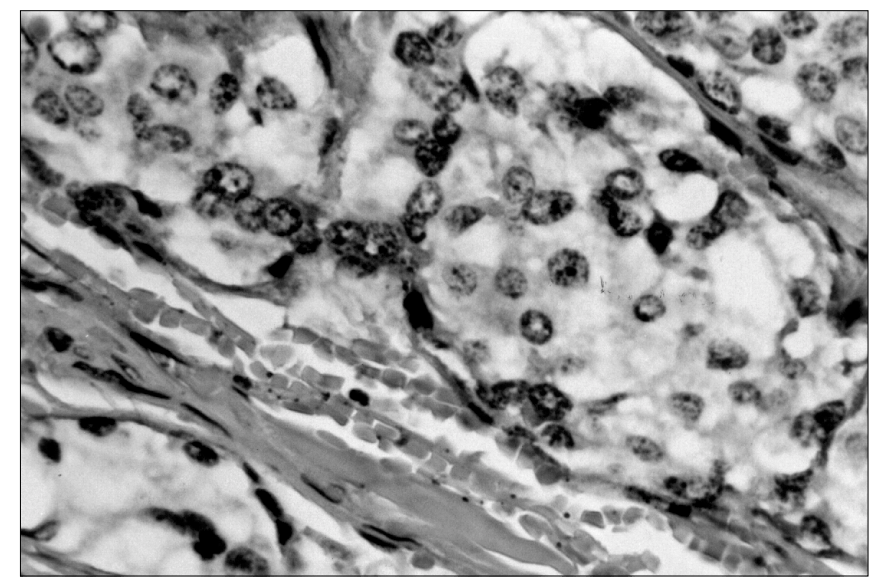

Figure 3. AgKi67 staining two nucleous.
From an analysis of the records of the $\mathrm{H}$ ead and N eck Serviceat H eliópolisH ospital, 8 cases of head and neck paragangliomas were found to have been submitted to surgical procedure at the $\mathrm{H}$ ead and N eck Service between 1977 and 1995. The following data were analyzed: time of complaint, family history, sex, age, site 
of thetumor, itssize (considering sizes as greater or less than $5 \mathrm{~cm}$ ) and metastases.

For the present study, new histological sections of thickness 3 micrometers were obtained from theold paraffin blocks. Theslides were stained with hematoxylin and eosin and other slides were also prepared for the immunohistochemical reactions. All slides were reviewed by the same pathologist. The architecture of the paraganglioma was evaluated and classified as follows:

a) $\mathrm{N}=$ nest pattern (classic or Zellballen pattern), with sustentacular cells (elongated cellswith indistinct cytoplasm) surrounding groups of principal cells (rounded or polyhedral cells that are eccentric, with granular cytoplasm) and vascular stromata;

b) $\mathrm{A}=$ Adenomatous: principal cells with marked similarity to epithelial cells, i.e. polyhedral cells with abundant cytoplasm organized in columns, surrounded by sustentacular cells and vascular stromata;

c) V = angiomatous: spindle-shaped principal cells, similar to endothelial cells, surrounded by sustentacular cells and vascular stromata; polymorphic principal cells, with few vascular stromata.

The predominant cell type in paragangliomas is the principal cell, accounting for 50 to $90 \%$ of the total number of cells. These cells are rounded, large, with prominent nuclei, eosinophilic cytoplasm rich in granules d) $S=$ solid: basically consisting of various

and ranging from 2 to 10 micrometers in diameter. These cells may vary in size and shape and wereclassified as follows: a) $\mathrm{C}=$ principal cells: 2 to 10 micrometers in diameter; b) $D=$ small cells: less than 2 micrometers in diameter; c) $\mathrm{E}=$ giant cells: more than 10 micrometers in diameter; d) F = fusiform cells: spindle-shaped cells, similar to vascular endothelium.

C ell atypia were evaluated and defined in terms of variation in shape and cell volume, the increase in the nucleus-cytoplasm relationship, irregularities in nuclear rims, nuclear hyperchromatism and the presence of nucleoli. They were semi-quantified as 0 (absent), 1 (mild), 2 (moderate) and 3 (accentuated).

In the immunohistochemical methods, three protein markers wereevaluated: AgK i67, chromogranin and S100 protein with amplification using the streptavidin-biotin-peroxidase complex. The immunohistochemical reactivity for AgKi67 (AcM iB-1) was evaluated by quantitative analysis: a) $1=$ rare cells (less than one per field at $400 x$ magnification); b) $2=$ moderate number of positive cells (up to $25 \%$ of cells); c) $3=$ high proportion of positive cells (greater than 25\%).

Asit was al ready known that there would not be any neoplasias unaccompanied by cell proliferation, then if there were any case with a negative reaction to chromogranin, this would not be considered valid and would therefore act as a further control for the reaction. The immunohistochemical reactivity to chromogranin (for principal cells) and S100

\begin{tabular}{lccccccc}
\hline \multicolumn{7}{c}{ Table 1, Distribution of patients and histopathological findings } \\
\hline CASE & Architecture & Cell type & Atypia & AgKi67 & S100 sustentacular/ principal cell & Chromogranin \\
\hline 1 & N & C & 0 & 1 & $1 / 0$ & 1 \\
\hline 2 & N +S & C & 1 & 1 & $3 / 2$ & 3 \\
\hline 3 & N +V & C & 3 & 1 & $3 / 2$ & 3 & 1 \\
\hline 4 & S+N & C & 2 & 1 & $3 / 1$ & 2 \\
\hline 5 & N +S & C & 2 & 1 & $2 / 0$ & 2 \\
\hline 6 & N & C & 2 & 1 & $3 / 2$ & 2 \\
\hline 7 & S & C & 2 & 1 & $1 / 0$ & 3 \\
\hline 8 & V & F & 1 & 2 & $2 / 0$ & & 2 \\
\hline
\end{tabular}

$N=$ nest pattern; $S=$ solid pattern; $V=$ angiomatous, $C=$ principal cells; $F=$ spindle cells.

Table 2. Relation between tumor size and cell atypia, chromogranin and AgK i67 reactivity, and sustentacular cell positivity to S100 protein reaction.

\begin{tabular}{|c|c|c|c|c|c|c|}
\hline & Tumor (size) & Atypia & Chromogranin & AgKi67 & \multicolumn{2}{|c|}{ S100 protein } \\
\hline \multirow{2}{*}{$<5$} & $-1+$ & $2(25 \%)$ & $1(12.5 \%)$ & $3(37.5 \%)$ & 0 & \\
\hline & $++1+++$ & $2(25 \%)$ & $3(37.5 \%)$ & $1(12.5 \%)$ & 4 & $(50 \%)$ \\
\hline \multirow{2}{*}{$>5$} & $-1+$ & $1(12.5 \%)$ & $1(12.5 \%)$ & $4(50 \%)$ & 2 & $(25 \%)$ \\
\hline & $++1+++$ & $3(37.5 \%)$ & $3(37.5 \%)$ & 0 & 2 & $(25 \%)$ \\
\hline
\end{tabular}

$-=$ negative; $+=$ rare staining cells; $++=$ moderate positivity; $+++=$ high positivity. protein (for principal and sustentacular cells) was eval uated by the following semi-quantification: a) 0 =negative; b) 1 = rare stained cells (less than 1 per field at 400x magnification); c) 2 moderate positivity (up to $25 \%$ of the cells); d) 3 = numerous positive cells (more than $25 \%$ of the cells).

RESU LTS

The distribution according to sex was 7 $(87.5 \%)$ of women and $1(12.5 \%)$ man, with a mean age of 39.5 years (range 23 - 77 years). At the time of the complaint, six patients $(75 \%)$ reported that the time of onset of the lesion had been more than 1 year earlier and 2 patients $(25 \%)$ reported it as being less than 1 year earlier. The main complaint in 7 cases $(87.5 \%)$ was a painless cervical tumor and in 1 case $(12.5 \%)$ it washearing loss and ear pain.

The distribution of patients in relation to the size of the tumor showed that 4 of them had a lesion of morethan $5 \mathrm{~cm}$ and 4 less than $5 \mathrm{~cm}$. The follow-up ranged from 1 to 132 months and no case of distant metastasis was noted.

The main histopathological and immunohistochemical findings are shown in Table 1 and Figures 1, 2, and 3.

There was a predominance of the nest pattern ( 5 cases: nos. 1, 2, 3, 5 and 6) and in 3 of them this was associated with other patterns (cases 2 and 5 with solid patterns, and case 3 with an angiomatouspattern). Thepredominant cell type was principal cells (7 cases: nos. 1, 2, 3, 4, 5, 6 and 7) and the remaining case had spindle-shaped cells as the main type (case 8).

Table 2 shows the relationships between tumor size and cell atypia, chromogranin re activity, AgKi67 reactivity and positivity to S100 protein reaction for sustentacular cells.

The relationships between cell proliferation among principal cells and chromogranin, and between sustentacular cells and S100 protein, are shown in Table 3.

The clinical-pathological characteristics are presented in Table 4, in which it can be noted that 5 cases $(62.5 \%)$ had a moderate to numerous quantity of cells reactive to $\mathrm{S} 100$ and chromogranin (cases 2, 3, 5, 6 and 8).

\begin{tabular}{|c|c|c|}
\hline \multirow{2}{*}{$\begin{array}{l}\text { hromogranin } \\
\text { principal cells) }\end{array}$} & \multicolumn{2}{|c|}{ S100 (sustentacular cells) } \\
\hline & $-1+$ & $++/+++$ \\
\hline+ & $1(12.5 \%)$ & $1(12.5 \%)$ \\
\hline$+1+++$ & $1(12.5 \%)$ & $5(62.5 \%)$ \\
\hline
\end{tabular}

-=negative; $+=$ rare staining cells; $++=$ moderate positivity; $+++=$ high positivity. 


\section{........ DISCUSSION}

The uncertain nature of head and neck paragangliomas makes their therapeutic management controversial. The clinical and epidemiological understanding still allows for some liberty of choice that discourages standardization of the approach to this disease. It is not clear why certain paragangliomas with same histopathological pattern follow different courses. These continuing uncertainties have justified new research ranging from epidemiological to cytogenetic studies, with the aim of identifying thebiological behavior of thetumor.

Thesymptoms of thesetumors arevolumedependent, such that their slow growth leads to the characteristics of an insidious disease. In a study among inhabitants of higher altitudes, ${ }^{24}$ it wasfound that the tumors evolved more rapidly. In that study, the female to male ratio was 8.3:1 with a mean age of 49 years. Tumors of the carotid body represented $79 \%$ of the cases of tumors of thepara-pharyngeal spaceand the incidence of malignancy was 3.3\%. Thesize of the tumor ranged from 2 to $12 \mathrm{~cm}$ (mean of $5.4 \mathrm{~cm}$ ) and $1 \%$ of the cases had a family history. ${ }^{24}$ Such results have been confirmed by other authors. ${ }^{19}$

In the present study, the mean evolution time for the disease was 17.5 months, with women predominating $(7: 1)$ and a mean age of 39.5 years old. M ost of thetumors ( $87.5 \%$ ) were from the carotid body and $12.5 \%$ from the tympanic cavity. The mean size of the tumor was $4.81 \mathrm{~cm}$ and no reports of a family history werefound. Thefemale predominance differs from reports in the literature, except those from high altitudes. The mean age, size of tumor and site distribution were similar to those reported in the literature. There were no cases of multicentricity, family history, re lapse and malignancy. The low number of cases could have led to a bias.

C ell atypia were found in cases 2, 3, 4, 5, 6,7 and 8 , of which five (cases $3,4,5,6$ and 7) had moderate to accentuated atypia. In addition, cellular necrosis was found in cases 3 and 5. The cell atypia data were correlated to the size of the tumor and this size was related to thereaction to AgK i67, chromogranin and S100 protein. In tumors bigger than 5 $\mathrm{cm}, 37.5 \%$ presented moderate to accentuated atypia. The relationship between size of tumor and tumor markers was not significant.

In studies using optical and electron microscopy, ${ }^{10}$ an absence of sustentacular cells has been noted in malignant paragangliomas ${ }^{24}$ and their metastases. T his has triggered a new era in the study of paragangliomas. Sustentacular cells, previously less easily identifiable under the optical microscope because of confusion with vascular pericytes, have become better understood using electron microscopy.

N evertheless, the task of identification has remained difficult and slow. We have simplified the task via immunohistochemical techniques, enhancing diagnoses and providing correlations with other aspects that assist in understanding the biological behavior of these tumors.

In a study using protein markers, ${ }^{4}$ two excellent markersfor principal cells (of which thereare greater quantitiesthan of sustentacular cells) were detected that, when used in combination, gave $100 \%$ sensitivity for neuroendocrine neoplasms. These markers are divided into two groups: (1) enzymatic markers, represented by AgK i67, and (2) specific protein granules, represented by chromogranin. Their reactions can differentiate the true cases of paragangliomas from carcinomatoustumors. Chromogranin and AgK i67 correlatewith the cell differentiation patterns of these tumors. Tumors that are more differentiated are moresimilar to normal tissueand, in consequence, they contain more cytoplasmic granules and re act moreintensely to thesemarkers. $0 \mathrm{n}$ theother hand, undifferentiated tumors haveless reactivity to chromogranin and AgK i67. In that samestudy, ${ }^{4}$ an absence of S100 protein wasnoted in malignant paragangliomas. Some studies have found different degrees of reactivity to thesemarkersfor principal cells, with theloss of reactivity being related to malignancy. ${ }^{25} \mathrm{C}$ ontroversy persistsregard- ing the real decrease in sustentacular cells in malignant tumors. O neimportant point isthat there is no case of malignant paraganglioma with sustentacular cells. ${ }^{24}$

S100 protein is well identified in the cytoplasm and nuclei of sustentacular cells and undergoes diminution in neoplasias. T hepresence of numerous sustentacular cells is highly associated with benign paragangliomas. The inverse is also true: a lack of sustentacular cells is associated with more undifferentiated and therefore malignant tumors. This consumption or disappearance of sustentacular cellsstill does not have any explanation.

Comparing the results of the present study, the immunohistochemical reactions were unspecific and variable. $0 \mathrm{n}$ the other hand, in the relationship between chromogranin in principal cells and S100 in sustentacular cells, $62.5 \%$ of the reactions were moderate to accentuated. T hese data may represent the course of the cases of benign disease, i.e. an absence of recurrence and metastasis. This affects the treatment because, de pending on the site of tumor, its size and the patient's age, a more aggressive adjuvant treatment may be avoidable. If this information were available before treatment, wewould certainly be more conservative and might even contra-indicate elective surgical treatment.

Radiotherapy may be an alternative treatment. In one study, ${ }^{26}$ fibrosis was observed between sustentacular cells and the perivascular network in irradiated patients. Therewas control of tumor growth despite the lack of noticeable effect on principal cells. ${ }^{26}$ In patients over 60 years old and at high risk in relation to anesthesia, this may be the treatment of choice. Such a choice is based exclusively on clinical experience and can be justified by the insidious behavior of the disease. ${ }^{27}$

We believe that present-day advances in biochemical science allow a much more solid therapeutic approach guided by prognostic factors. Faced with a case of head and neck paraganglioma, in addition to the detailed clinical

\begin{tabular}{|c|c|c|c|c|c|c|c|}
\hline Case no. & age/ sex & place & symptom & histology & metastasis & Treatment & follow-up \\
\hline 1 & $23 / F$ & carotid & 12 months & $\mathrm{N}$ & - & Surgery & 6 months \\
\hline 2 & $77 / \mathrm{F}$ & carotid & 6 months & $\mathrm{N}+\mathrm{S}$ & - & Surgery & 13 months \\
\hline 3 & $30 / \mathrm{M}$ & carotid & 6 months & $\mathrm{N}+\mathrm{V}$ & - & Surgery & 132 months \\
\hline 4 & $32 / F$ & carotid & 48 months & $\mathrm{S}+\mathrm{N}$ & - & Surgery & 1 month \\
\hline 5 & $47 / F$ & carotid & 12 months & $\mathrm{N}+\mathrm{S}$ & - & Surgery & 89 months \\
\hline 6 & $32 / F$ & carotid & 20 months & $\mathrm{N}$ & - & Surgery & 1 month \\
\hline 7 & $36 / F$ & carotid & 12 months & $S$ & - & Surgery & 12 months \\
\hline 8 & $39 / F$ & tympanic & 24 months & V & - & Surgery & 5 months \\
\hline
\end{tabular}

Classic Pattern = Zellballen; $V=$ angiomatous; $S=$ solid. 
analysis, imaging studies and anatomopathological studies of the surgical specimen, we can make use of immunohistochemical methodsin assisting usto differentiate between benign and malignant tumor cases
.............. CONCLUSION

We can confirm that chromogranin proved to beageneric marker for neuroendocrinetumors, the $\mathrm{S} 100$ protein was positive in all cases and the cell proliferation marker AgKi67 showed low positivity in all cases but one. Finally, $62.5 \%$ of the cases showed moderate to strong reaction to chromogranin and S100 protein, which wasconsistent with thebenign evolution of thesetumors.
1. van der M A, CornelisseC, H ermans], et al. D N A flow cytometry of hereditary and sporadic paragangliomas (glomus tumours). $\mathrm{Br}$ J Cancer 1991;63:298-302.

2. Bosq F, M icheau C, N ivet P, Luboinski B. Paragangliomas of the head and neck: immunohistochemical analysis of 16 cases in comparison with neuroendocrinecarcinomas. Path Res Pract 1991;187:814-23.

3. Grimley P, G lenner G. H istology and ultrastructure of carotid body paragangliomas: comparison with the normal gland. $\mathrm{Can}$ cer 1967;20:1473-88.

4. Kliewer K, Wen D, Cancilla P, Cochran A. Paragangliomas: assessment of prognosis by histological, immunohistochemical, and ultrastructural techniques. Human Pathology 1989;20:29-39.

5. Fruhwirth J, Koch $\mathrm{G}, \mathrm{H}$ auser $\mathrm{H}$, et al. Paragangliomas of the carotid bifurcation: oncological aspects of vascular surgery. Eur J Surg Oncol 1996;22:88-92.

6. Heymans C, Bouckaert C. Les chémo-récepteurs du sinus carotidien. Ergebn Physiol 1939;41:28-55.

7. Arias-Stella J, Valcarce J. Chief cell hyperplasia in the human carotid body at high altitudes. Hum Physiol 1976;7:361-73.

8. CapellaC, RivaC, Cornaggia M , Chiaravalli M, Frigerio B. Histopathology, cytology and cytochemistry of pheochromocytomas and paragangliomas including chemodectomas. Path Res Pract 1988;183:176-87
9. Lecompte P. Tumors of the carotid body. Am J Pathol 1948;24:305-21

10. Robertson $\mathrm{D}, \mathrm{C}$ ooney T. M alignant carotid body paraganglioma light and electron microscopic study of the tumor and its metas tasis. Cancer 1980;46:2623-33.

11. Ryse-D avies J, D awson I, Wetbury G. Some morphological, histochemical, and chemical observations on chemodectomas and the normal carotid body, including a study of the chromaffin reaction and possible ganglion cell dements. Cancer 1964;17:185-202.

12. Lloyd R, Sisson J, Shapiro B, Verhofstad A. Immunohistochemical localization of epinephrine, norepinephrine, catecholamine synthesizing enzymes and chromogranin in neuroendocrine cells and tumors. Am J Pathol 1986;125:45-54

13. Levit S, Sheps S, Espinosa R, Remine W, H arrison E. Catecholamine-secreting paraganglioma of glomus-jugular region resembling pheochromocytoma. N ew Engl J M ed 1969;281:805-11.

14. Glasscock M, Jackson C, N issen A, Smith P. Diagnosis and management of catecholamine secreting glomus tumors. Laryngoscope 1984;94:1008-15

15. M cC affrey T, M eyer F, M ichels V, Peipgras D, M arion, M . Fa milial paragangliomas of the head and neck. Arch 0 tolaryngol H ead N eck Surg 1994;120:1211-6.

16. Zaslav A, M yssiorek D, M ucia C, Fox J. Cytogenetic analysis of tissues from patients with familial paragangliomas of the head and neck. H ead \& N eck 1995;17:102-7.
17. Wang D, Barros A, Johnston C, Buchanan K. O ncogene expres sion in carotid body tumors. Cancer 1996;77:2581-7.

18. Wang D, Johnston C, Barros A, Buchanan K. Expression of apoptosis-suppressing gene bcl-2 in human carotid body tumors | Pathol 1997:183:218-21.

19. Lack E, Cibilla A, Woodruff J, Farr H. Paragangliomas of the head and neck region: a clinical study of 69 patients. Cancer 1977;39:397-409.

20. Shamblin W, Remine W, Sheps S, H arrison E. Carotid body tumor (chemodectoma): clinicopathological analysis of ninety cases. Am J Surg 1971;122:732-9.

21. M oberg A. M alignant carotid body tumor with metastases in the lungs. Acta Otolaryngol 1961;53:590-4.

22. Romanski R. Chemodectoma (non-chromaffin paraganglioma) of the carotid body with distant metastases. Am J Pathol 1954;30:1-9.

23. Schwarting R. Little missed markers and Ki67. Lab Invest 1993;68:597-9.

24. Rodríguez-Cuevas S, López-Garza J, Labastida-Almendaro S Carotid body tumorsin inhabitants of altitudeshigher than 2000 meters above sea level. H ead \& N eck 1998;20:374-8.

25. Kliewer K, Cochran A, Wen D, Cheng L, Cancilla P. An immunohistochemical study of 37 paragangliomas. Med Sci Res 1987; 15:87-8

26. SilverstoneS. Radiation therapy of glomus jugular tumors. Arch Otolaryngol 1973:97:43-8
.. Publ ish ing in for mation.

Pedro de Alcântara de Andrade Filho, MD. Head and N eck Surgery, Hospital Heliópolis, São Paulo, Brazil.

Abrão Rapoport, MD, PhD. Head and N eck Surgery, Hospital Heliópolis (Hosphel), São Paulo, Brazil.

Venâncio Avancini Ferreira Alves, MD, PhD. Pathology, Faculdade de M edicina da Universidade de São Paulo, São Paulo, Brazil.

Odilon Victor Porto Denardin, PhD. Head and N eck Surgery, Hospital Heliópolis, São Paulo, Brazil.

Josias de Andrade Sobrinho, PhD. Head and N eck Surgery, Hospital Heliópolis, São Paulo, Brazil.

Marcos Brasilino de Carvalho, PhD. Head and N eck Surgery, Hospital Heliópolis, São Paulo, Brazil.

Sources of funding: MEC/ CAPES DS 066/96

Conflict of interest: $\mathrm{N}$ ot declared

Last received: 28 A pril 2000

Accepted: 03 M ay 2000

Address for correspondence

Abrão Rapoport

Praça A madeu Amaral, 47 - cj. 82

São Paulo/ SP - Brazil - CEP 01327-010

E-mail: cpgcp.hosphel@attglobal.net

CO PYRIG HTO2001, Associação Paulista de Medicina

RESUMO

CONTEXTO : . A marcação positiva pode auxiliar na escolha da terapêtica dos paragangliomas de cabeça e pescoço. A definição do tratamento deve ser realizada incorporando o resultado desses testes.

O BJET IVO : Por meio do estudo da relação do sexo, idade, tamanho de lesão, tempo de queixa, localização, história familiar, metástase, tratamento, arquitetura, tipo celular com as reações imunohistoquímicas para proteína $\mathrm{S} 100$, cromogranina e AgK i67, estabelecimento de critérios de benignidade e malignidade dos paragangliomas vagais e júgulo-timpânicos.

TIPO DE EST UD 0: Estudo retrospectivo de arquivos histológicos e clínicos.

LOCAL: H ospital Heliópolis e 0 swaldo Cruz, São Paulo.
PARTICIPANTES: O ito casos de paragangliomas de cabeça e pescoço.

VARIÁVEIS ESTUDADAS: Grau de positividade para paragangliomas com reação imunohistoquímica.

RESULTAD O S: 0 smarcadores protéicos para as células principais (AgKi67 e cromogranina) foram sensíveis em $100 \%$ das neoplasias quando usados conjuntamente; A proteína S100 foi bem identificada no citoplasma e núcleo das células sustentaculares e sofre diminuição nas neoplasias.

CO N C LU SÕ ES: a cromogranina comprovou ser um marcador genérico para os tumoresneuroendócrinas, a proténa S100 foi positiva nos oito casos e $\mathrm{Ki} 67$ foi baixo em todosos casos.

PALAVRAS-CH AVE: Paragangliomas. M arcadores. AgKi67. Cromogranina e proténa $S 100$. 